\title{
DECOMPOSITION AND NUTRIENT RELEASE OF SAL LEAF LITTER AS INFLUENCED BY LEGUME LEAF LITTER OF THE $S A L$ FORESTS
}

\author{
Tania Sultana, Mohammad Zabed Hossain*, Ashfaque Ahmed \\ AND SiRAJUl HOQUE ${ }^{1}$ \\ Department of Botany, University of Dhaka, Dhaka-1000, Bangladesh
}

Key words: Decomposition, Nutrient, Release, Sal leaf litter, Legume leaf litter

Decomposition of litter is an important function that determines nutrient and carbon cycling in the forest ecosystems. Litter quality largely influences the rate of decomposition; high levels of nutrients such as nitrogen $(\mathrm{N})$ and phosphorus $(\mathrm{P})$ enhance the rate of microbial decomposition and mineralization and those of defense chemicals such as phenolic compounds and tannins slow down the rate of that processes $(1,2,3)$. Plant species differ greatly in decomposability of litter( ${ }^{(4,5)}$. Leguminous plants produce high quality litter having increased $\mathrm{N}$ and $\mathrm{P}$ in their plant tissues because of the capability to fix atmospheric $\mathrm{N}$ and also of the ability to uptake increased $\mathrm{P}$ through mycorrhizal association ${ }^{(6,78)}$. In Sal forests, dominated by Sal (Shorea robusta Gaert. ex f.), of Bangladesh about $70-75 \%$ of the trees are Sal and among the total of 54 families recorded, Leguminosae is the largest with 24 species under 15 genera $^{(9)}$. Although leguminous plants are naturally associated with Sal plants(10), the role of these plants on decomposition and nutrient mineralization of the litter of Sal plants has not been well studied, although such information is relevant for the management and conservation of the Sal forests. The main objective of the present study was to examine the effects of legume leaf litter on mass loss and the release of N and P of the Sal leaf litter in Sal forests.

Leaf litter was collected from four legume species, namely Butea monosperma, Acacia auriculiformis, Albizia procera and Desmodium heterophyllum along with S. robusta growing naturally in the Sal forest under the districts of Gazipur, Tangail and Mymensingh. Soil was collected from nine different sites at $0-10 \mathrm{~cm}$ depth and then mixed together and kept in a plastic bag. Dried leaves of legume plants were then added separately to $200 \mathrm{~g}$ soil already taken into a plastic pot. The dried leaf litter of Sal plants was cut into pieces of $2 \mathrm{~cm} \times 2 \mathrm{~cm}$ in size. Then, $1 \mathrm{~g}$ Sal leaf was added to each pot containing legume leaf litter mixed with soil. In addition to litter treatments, control (soil without legume leaf litter) was also used. Each treatment was replicated three times. Autoclaved distilled

*Author for corresponding: <zabed@du.ac.bd>.1Department of Soil, Water and Environment, University of Dhaka, Dhaka 1000, Bangladesh. 
water was added time to time in order to maintain moisture content similar to all treatments. Pots were kept for incubation at room temperature. Samples were collected after three to six months for the analysis of mass loss rate and N and P contents in Sal leaf litter. Leaf N, P, phenolics and tannins were determined by following standard protocols as described by Hossain et al.(11).

As shown in Table 1, the highest total $\mathrm{N}$ content was recorded in A. auriculiformis $(1.46 \%)$ and the lowest of that was recorded in S. robusta $(1.09 \%)$, although no significant difference appeared. Leaf $\mathrm{P}$ content showed significant difference among the litter species. Phosphorus content was highest in A. procera $(0.29 \%)$ and that was lowest in $S$. robusta $(0.09 \%)$. Leaf phenol content also showed significant difference among the five plant species. Concentration of phenol was highest in D. heterophyllum $(2.88 \%)$ and lowest in S. robusta (1.31\%). Tannin content was also highest in D. heterophyllum $(0.05 \%)$ but lowest in A. procera $(0.003 \%)$ with marginal significance $(\mathrm{p}=0.06)$.

Table 1. Chemical properties of leaf litter of the different plant species used in the study.

\begin{tabular}{lcccccc}
\hline & $\begin{array}{c}\text { Acacia } \\
\text { auriculiformis }\end{array}$ & $\begin{array}{c}\text { Albizia } \\
\text { procera }\end{array}$ & $\begin{array}{c}\text { Butea } \\
\text { monosperma }\end{array}$ & $\begin{array}{c}\text { Desmodium } \\
\text { heterophyllum }\end{array}$ & $\begin{array}{c}\text { Shorea } \\
\text { robusta }\end{array}$ & $\mathrm{p}$ \\
\hline Nitrogen (\%) & $1.46 \pm 0.08$ & $1.13 \pm 0.08$ & $1.23 \pm 0.08$ & $1.19 \pm 0.08$ & $1.09 \pm 0.08$ & 0.08 \\
Phosphorus (\%) & $0.10 \pm 0.04$ & $0.29 \pm 0.04$ & $0.19 \pm 0.04$ & $0.11 \pm 0.04$ & $0.09 \pm 0.04$ & 0.04 \\
Phenol (\%) & $1.47 \pm 0.35$ & $1.52 \pm 0.35$ & $2.39 \pm 0.35$ & $2.88 \pm 0.35$ & $1.31 \pm 0.35$ & 0.04 \\
Tannin (\%) & $0.01 \pm 0.01$ & $0.003 \pm 0.01$ & $0.03 \pm 0.01$ & $0.05 \pm 0.01$ & $0.03 \pm 0.01$ & 0.06 \\
\hline
\end{tabular}

Two-way ANOVA revealed that mass loss and $\mathrm{N}$ content in Sal leaf litter was significantly $(p<0.0001)$ affected by time of incubation but not by litter species. Species effect was significant $(\mathrm{p}=0.03)$ for leaf $\mathrm{P}(\%)$ content during decomposition (Fig. 1). There was no significant interaction between litter species and time on the variables studied in the present study.

Mass remaining and $\mathrm{N}$ content of the leaf litter gradually declined from initial through three months to six months. After six months, about $50 \%$ mass remained in Sal leaf litter incubated with A. auriculiformis and B. monosperma. Although there was no significant effect of litter species on leaf $\mathrm{N}$ content there was a tendency of lower leaf $\mathrm{N}$ content in Sal leaf litter treated with the leaf litter of the four legume species compared to control. Leaf P content of Sal leaf litter gradually decreased from initial to six months while incubated with leaf litter of $A$. procera and increased when incubated with that of D. heterophyllum.

Significant effect of legume litter species on the release of P content in Sal leaf litter could be explained by the differences in the litter chemistry of the plant species used in the experiment. The lowest and the highest amount of $\mathrm{P}$ were reported in Sal leaf when it 

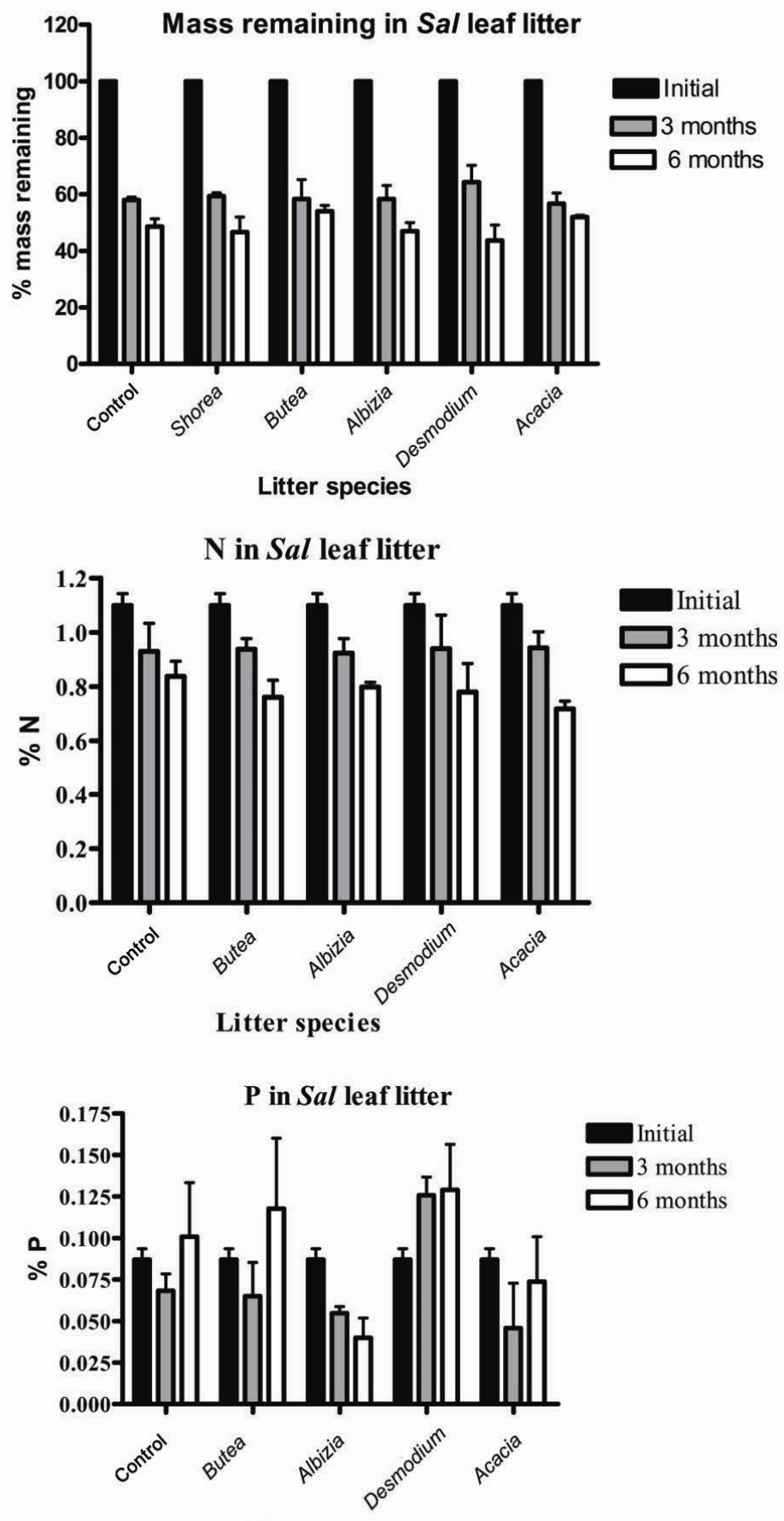

Litter species

Fig. 1. Effects of leaf litter of various plant species on the mass loss rate and $\mathrm{N}$ and $\mathrm{P}$ remaining in the Sal leaf litter. 
was incubated with $A$. procera and $D$. heterophyllum, respectively. Further, A. procera contained the lowest amount of tannin while D. heterophyllum contained the highest amount of phenolic substances. It is reported that phenolic substances inhibit microbial

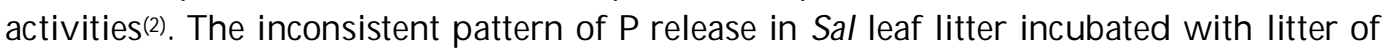
different legume species observed in the present study is consistent with other studies those reported accumulation of $\mathrm{P}$ in the decomposing leaf litter ${ }^{(12)}$. All these results of the present study are thus relevant for the management and conservation of the deciduous Sal forest ecosystems.

\section{References}

1. Enriquez S, M Duarte and K Sand-Jensen 1993. Patterns in decomposition rates among photosynthetic organisms: the importance of detritus $C: N$ : P content. Oecologia 94: $457-471$.

2. Hättenschwiler S and P Gasser 2005. Soil animals alter plant litter diversity effects on decomposition. Proc. Nat. Acad. Sci. 102: 1519-1524.

3. Hättenschwiler S and PM Vitousec 2000. The role of polyphenols in terrestrial ecosystem nutrient cycling. Trends Ecol. Evol. 15: 238-243.

4. Cornelissen JHC 1996. An experimental comparison of leaf decomposition of temperate plant species and types. J. Ecol. 84: 573-582.

5. Grime JP, HC Cornelissen, K Thompson and JG Hodgson 1996. Evidence of a causal connection between anti-herbivore defense and the decomposition rate of leaves. Oikos. 77: 489-494.

6. France C, L Kristina and E Claudine 2009. Nitrogen-fixing bacteria associated with leguminous and non- leguminous plants. Plant Soil. 321: 35-59.

7. Bolan NS 1991. A critical-review on the role of mycorrhizal fungi in the uptake of phosphorus by plants. Plant Soil. 134: 189-207.

8. Scheublin TR, RSPV Logtestijn and MGA van der Heijden 2007. Presence and identity of arbuscular mycorrhizal fungi influence competitive interactions between plant species. J. Ecol. 95: 631- 638.

9. Malaker JC, MM Rahman, AKMA Prodhan, SK Malaker and MAH Khan 2010. Floristic composition of Madhupur Sal forest in Bangladesh. J. Soil Nat. 4: 25-33.

10. Khan MS 1991. The vegetation of Bangladesh. In: Plant life of South Asia (Ali SI and A Gaffar Eds.). pp. 185-192.

11. Hossain MZ, O Atsushi and S Sugiyama. 2010. Effects of grassland species on decomposition of litter and soil microbial communities. Ecological Res. 25: 255-261.

12. Colpaert JV and KK van Tichelen 1996. Decomposition, nitrogen and phosphorus mineralization from Beach leaf litter colonized by Ectomycorrhizal or litter-decomposing Basidiomycetes. New Phytol. 134: 123-132. 